\title{
Using Center Learning in Building Early Childhood Character
}

\author{
Hani Septiani Ardin ${ }^{1}$, Syafrimen Syafril ${ }^{2 *}$ \\ ${ }^{1,2}$ Universitas Islam Negeri Raden Intan Lampung, Indonesia \\ *syafrimen@radenintan.ac.id
}

\begin{abstract}
Building children's character from an early age is important, because children's character is the main key to developing quality resources. One of the problems that is often encountered in building early childhood character is the use of learning methods that are not suitable for early childhood development. One of the learning methods that are suitable for early childhood development is the center learning method. Building the character of early childhood during the pandemic Covid-19 is a new challenge for teachers, because learning is done online. However, using face-to-face learning center learning methods can be done virtually by utilizing technology. Based on the analysis carried out from 98 scientific articles published in various reputable journals in various countries (Japan, Europe, Korea, China, India, Australia, England and Indonesia), it was found that center learning can be used as an alternative to help teachers build character. early childhood. Central learning is assumed to be in accordance with early childhood development which emphasizes the principle of learning while playing. For this reason, center learning can be an option for teachers in the learning process, especially in building early childhood character. In fact, teachers need to be given special skills related to how to apply this learning center, so that the process of character building for early childhood can still be done even though face-to-face learning is done virtually.
\end{abstract}

Keywords: character building; learning center; learning online, quality resources; early childhood

\section{Penerapan Pembelajaran Sentra Dalam Membangun Karakter Anak Usia Dini}

\begin{abstract}
Abstrak
Membangun karakter anak sejak usia dini penting dilakukan, karena karakter anak merupakan kunci utama pembangunan sumber daya berkualitas. Salah satu permasalahan yang sering dijumpai dalam membangun karakter anak usia dini adalah penggunaan metode pembelajaran yang kurang sesuai dengan perkembangan anak usia dini tersebut. Salah satu metode pembelajaran yang sesuai dengan perkembangan anak usia dini adalah metode pembelajaran sentra. Membangun karakter anak usia dini pada masa pandemi covid-19 menjadi tantangan baru bagi guru, karena pembelajaran dilakukan secara daring. Bagaimanapun, menggunakan metode pembelajaran sentra pembelajaran tatap muka bisa dilakukan secara virtual dengan memanfaatkan teknologi. Berdasarkan analisis yang dilakukan dari 98 artikel ilmiyah yang dipublish dalam bergai Jurnal bereputasi di berbagai Negara (Jepang, Eropa, Korea, China, India, Australia, Inggris dan Indonesia) didapati bahwa pembelajaran sentra dapat dijadikan sebagai salah satu alternatif untuk membantu guru dalam membangun karakter anak usia dini. Pembelajaran sentra diasumsikan sesuai dengan perkembangan anak usia dini yang mengedepankan prinsip belajar sambil bermain. Untuk itu pembelajaran sentra dapat menjadi salah satu pilihan bagi guru dalam proses pembelajaran, khususnya dalam membangun karakter anak usia dini. Justru, guru perlu diberikan keterampilan khusus terkait cara menerapkan pembelajaran sentra tersebut, supaya proses pembangunan karakter anak usia dini tetap bisa dilakukan walaupun pembelajaran tatap muka dilakukan secara virtual.
\end{abstract}

Kata Kunci: membangun karakter; pembelajaran sentra; pembelajaran daring; sumber daya berkualitas; anak usia dini 


\section{INTRODUCTION}

Building children's character must be started at an early age because their characters can reflect their future behavior (Silahuddin, 2017). Kim states that the early childhood character can affect activities, interactions, and life choices (Kim et al., 2019). Character is also essential to shaping personality (Agusti et al., 2018) and the quality of children to build a Golden Generation (Kiritin \& Darsono, 2019). Someone who has good character will have a positive, caring, fair, honest, forgiving, respect for one another, and be aware of social life (Indriani, 2017). However, the fact is that there are still many Early Childhood Education (PAUD) institutions that in the learning process only provide academic knowledge (Sanderiani, 2020) even though in the learning process, building character is an essential foundation that must be instilled in children from an early age (Bustan \& Fitria, 2017).

Early childhood character requires the correct method (Bahar et al., 2020), especially during a pandemic. Learning is carried out online and provides a new challenge to build early childhood character (Hignasari \& Wijaya, 2020). Previous research has investigated the character development of early childhood using several methods. In the research conducted by Afandi et al., the application of methods to build children's character through online fable found seven-character values: polite, friend, humble, environmental care, curiosity, fairness, and decision-makers (Afandi \& Juanda, 2020). Furthermore, using the learning center method can form eight characters, including religious, disciplined, honest, independent, creative, hard work, friendly and responsible (Ramadhanti et al., 2019). According to Iswaningtyas, the learning center method is believed to stimulate all aspects of children's intelligence and foster children's character through directed play activities. Thus the character development of early childhood can be instilled appropriately using the learning center method. This is proven in his research that the eighteen values of character education set by the Ministry of Education and Culture can be easily instilled in early childhood using the learning center method (Iswantiningtyas \& Wulansari, 2019).

Character building in Japan is instilled through moral and personality education from early childhood (Mulyadi, 2020). Some of the media that previous researchers have used to help build children's character, namely media e-learning that supports distance learning and proven by e-learning, can build children's character in collecting assignments given by the teacher (Sahudra et al., 2020). The use of wayang suket can make children understand the character values in wayang characters which can then be applied in everyday life (Satria \& 
Kasiyan, 2020). Character education can also be built from characters in animated films (Astuti et al., 2019) and learning using digital comic media (Rina et al., 2020).

There are six principles of early childhood learning including: (1) orienting to children's needs, (2) designing activities carefully, (3) orienting to children's character development, (4) implementing it gradually and repeatedly, (5) learning with a footing, and (6) learning by playing. Children can feel these six principles only in the learning center (Muhsinin \& Navi, 2017). By applying the learning center method can be a solution to answer the challenges of learning currently carried out online (Mufaziah \& Fauziah, 2020) to build children's character (Samsinar \& Fitriani, 2020) by utilizing technology as a communication tool (Arwen \& Puspita, 2020). Kim has researched early childhood character building using the learning center method in 2019 in Korea, Xiang in 2020 in China, Singh in 2019 in India, Kristjánsson in 2020 in England, Van Acker in 2018 in Australia, Lucas in 2016 in Europe, and Bahar in 2020, Ramadhanti in 2019, Iswaningtyas in 2019, Mulyadi in 2020, Satria in 2020, and Astuti in 2019 in Indonesia.

\section{RESEARCH METHOD}

This article is a paper concept to see the application of learning centers in building early childhood character. Data is taken from various scientific publications in leading journals from various countries, including Japan, Europe, Korea, China, India, Australia, England, and Indonesia.

\section{RESULTS AND DISCUSSION}

\section{a. Problems in Building Early Childhood Character}

In building character in early childhood, there are still problems that cause many people to blame education for the failure of a person's character development (Atmazaki et al., 2020). Problems often encountered include many PAUD institutions forgetting their identity as builders of early childhood character foundation. They only give birth to intellectually intelligent children but weak in terms of character and morals (Hapidin \& Yenina, 2016). According to Hadiati, the field conditions in PAUD institutions have not implemented PAUD learning properly (Hadiati \& Fidrayani, 2019). Character development in early childhood is generally given much theory through storytelling methods (Maryatun, 2016); however, sometimes early childhood has difficulty understanding even though the teacher has explained it (Cinantya et al., 2018) only passively accept theory but have 
difficulty applying it. In everyday life (R. Gunawan, 2017). Learning that emphasizes the character building of early childhood is still rare (Xiang et al., 2020).

The use of learning methods that are not suitable in building children's character (Fathinnaufal \& Hidayati, 2020) (MTR Gunawan, 2020) results in the character being built that cannot be embedded correctly in children (Maputra et al., 2020) (Setiawan et al., 2020). As referred to in this article, the problems in building early childhood character refer to the problem of using learning methods in building early childhood character. Character development in early childhood is significant to form moral individuals because children's character is the primary key to developing quality resources (Chowdhury, 2016) to have good character values (Heriansyah, 2018). Children with good character will have good qualities and attitudes (Singh, 2019). Inculcating good habits in early childhood education by using learning methods suitable for early childhood development will make it easier for children to understand and apply them in everyday life (MD Wulandari \& Filmayasari, 2018). For this reason, choosing a suitable learning method is very important for building early childhood character.

\section{b. Learning center in Building Early Childhood Character}

Several research results in various countries in the world found that learning center is seen as one of the best choices for character building for early childhood because it emphasizes play. In his research in European countries, Lucas stated that playing is an appropriate learning method for early childhood (Lucas, 2017). Kim from Korea also argues that playing can build early childhood character (Kim et al., 2019). Thus, the learning center is the most appropriate method used in the PAUD learning process to build early childhood character.

A learning center is a learning approach carried out in circle times and play centers (Rahmawati, 2019). A play center is a children's play area or zone equipped with a set of play tools that serve as the foothold needed to develop all children's essential potential in a balanced manner (Fatmawati \& Latif, 2019). The learning center method is a method that uses a play approach, so children can gain knowledge and develop their abilities through playing activities or what is called learning by playing (Puspita et al., 2015). Early childhood has a dynamic nature, so that learning in early childhood is playing while learning, meaning that children learn in ways that are fun, active, and free (Supriatna et al., 2018). Free is meant not based on orders or targets of others and has the flexibility when it starts and when it ends. Thus students are free to develop their abilities to the maximum (Ramadhanti \& Safitri, 
2020). With learning centers, children will be more active and directly involved in meaningful games and learn well (Anna Fauza Jailani, Zulfadli A. Aziz, 2018).

The learning center is child-centered learning (Anhusadar, 2019). It is considered relevant with the stages of early childhood development because of its nature to prioritize aspects of playing according to the children's developmental phase and unique characteristics (Masrurah, 2020). Games are the primary material in early childhood education (Lucas, 2017), building children's character through real experiences (Van Acker et al., 2019). A good experience will positively impact children's growth and development (Widyastuti et al., 2018). A person who learns from experience will find his life more meaningful because experience gives him broader knowledge (Syafrimen Syafril et al., 2020). The playing method contains many moral values that are very important to be instilled from an early age, including cooperation, help, willingness to give in, and willing to accept defeat (W. Anggraini \& Syafril, 2018). In this case, teachers and parents must work together to understand children's development so that they can provide a stimulus that is following the child's characteristics (Widiastuti et al., 2019).

The learning center has a characteristic, namely the stages of the learning process consisting of a playing environment, a footing before playing, a foothold when playing, and a foothold after playing (Maimunah et al., 2018). The application of a learning center makes learning exciting and fun (Lestari, 2016), increases children's interest in learning (Sari et al., 2019), increases children's creativity (RT Wulandari, 2017), and provides opportunities for children to develop their abilities effectively and systematically (Tatminingsih, 2019) following the characteristics and level of child development (Yusnita, 2019). The principles of learning centers refer to the needs of children to develop more optimally (Hendra Sofyan et al., 2019). Playing activities using the learning center method emphasizes all learning activities focusing on children as learning subjects. In contrast, teachers play more of a role as motivators and facilitators by providing the foundations for the learning process (Oktaria \& Putra, 2020).

Through learning, the education center provides opportunities for children to develop their creativity (Ruqoyah, 2016), (Puteri et al., 2018) by providing opportunities for children to choose their activities according to their interests so that children's creativity can develop optimally (Khalifah et al. ., 2018) so that character values can also be embedded appropriately (ES Anggraini, 2020) which can foster good behavior (Setiyarini \& Widiasari, 2017). 
In the situation of the pandemic Covid-19, all children's play and learning activities are assisted by parents and carried out at home (Mutmainnah, 2020) by utilizing technology (S Syafril et al., 2021) and internet networks (Lestari et al., 2021). However, in these

Conditions the learning center method can still be used during distance learning (Shofa, 2020). According to Ulfah, a learning center is a proper method for distance learning (PJJ) applied during the pandemic Covid-19 by utilizing social media as an intermediary and working with parents to accompany children when learning online home (Ulfah, 2020). In online learning, the role of parents is essential to help provide education to children (Jain et al., 2019), especially character education because an important influence in building early childhood character is from the family, which is indeed the first character builder in children (Ma'rifah A \& Muthmainnah, 2015) including honesty, discipline, curiosity, and responsibility (Dj et al., 2020).

Learning center is very appropriate to be applied to early childhood education because learning center can be done anywhere and anytime (N. Hasanah \& Harmawati, 2020). Implementing the learning center method can be a solution to overcome the problem of character building for early childhood that cannot be done face-to-face in schools during the pandemic Covid-19 (Mufaziah \& Fauziah, 2020). In this case, teachers and parents are expected to maximize the use of technology (Srihartini \& Lestari, 2020) to support online learning centers with the help of parents who act as teachers at home.

In early childhood learning, the learning center method is the correct method for building early childhood character. This learning center method contains elements of Islamic values . It has the main objective of building moral, mental, and reasoning children to be better from an early age (Yusuf \& Akbar, 2020) and form quality children (Dewi, 2015). Another goal is to support the growth and development of children as a whole and provide knowledge and experience to have good character and readiness to continue to further education (Novia \& Mahyuddin, 2020).

Learning center is believed to be an effective learning method for early childhood. This can be proven from the opinion of researchers through the results of their research in several educational institutions (Mustajab et al., 2021). Raudatul Hasanah used the learning center method at TK Khalifah Baciro Yogyakarta. He got satisfactory results and ran optimally and pleasantly (R. Hasanah \& Abdul, 2019). Apriliani, in her research at Tirtayasa Serang Islamic Kindergarten, applies the learning center method to provide opportunities for children to explore their knowledge with the help of teachers or parents as facilitators, motivators and evaluators (Apriliani et al., 2020). According to Suyadi, learning carried out 
with games will make children feel happy, excited, and not easily bored (Suyadi, 2017) and will make children's learning motivation higher (Setiyarini et al., 2015). By playing, children can learn to achieve physical, emotional, intellectual, and social development (Yuningsih et al., 2018).

The advantages of the learning center method are: (1) The stages of child development are formulated in detail and clearly so that the teacher can assess the child's development according to the level of development in each child's needs. (2) Learning activities are sequential and arranged, starting from the arrangement of the playing environment to giving directions. (3) Every child gets support to learn actively, creatively, and dare to make decisions. (4) Learning center is not rigid. (5) Learning is carried out in stages, continuously, and is accustomed. (6) Child-centered learning, namely learning activities carried out by encouraging children to play in-game centers, while teachers act as designers, supporters, and assessors of children's activities (Yadnyawati, 2019).

The application of the learning center model has many benefits, including: (1) providing a pleasant play experience, (2) providing a quality play environment, (3) providing stimulus to children through learning that is focused on independence, providing a calm learning environment and learning that is child-centered, (4) stimulates children's activeness in playing in game centers, (5) children can develop their abilities freely and optimally (Wahyuningsih, 2020), (Sobarna \& Hakim, 2017), (6) can make decisions and be responsible for decisions made (Murestiyanto, 2019), (7) care about Indonesia's cultural diversity (Khairunisa \& Wahab, 2019), (8) and train mentally and morally to become a quality generation (Abdi, 2018).

Early childhood is a play for children because children tend to spend more time playing than learning. Therefore teachers need to provide learning for early childhood through play (Wiwik Pratiwi, 2017). The learning center method is the right offer to use in building early childhood characters because the learning center method is a method that uses a play approach (Arifin \& Fardana, 2014) so that learning becomes exciting and fun (Syafrimen Syafril et al., 2021). Playing for children provides satisfaction for children and can also build character and shape children's attitudes and personalities (Wiwik Pratiwi, 2017). Character is the primary key determining a person's behavior in the future (Zurqoni et al., 2018). Good children's behavior, such as honesty, discipline, and others, are behaviors that are demanded by children (Mardi Fitri \& Na'imah, 2020). Therefore, children's character needs to be built to bring out good behavior in children. 
Building children's character from an early age is the obligation of a teacher to form a generation that has noble character (Farisia, 2020). Characters taught to children from an early age will continue to stick until the child is an adult (Yusuf \& Akbar, 2020) and forms a personality reflected in their behavior (Kristjánsson, 2020). Learning centers can be used as an innovation to build early childhood character (Purnama \& Abadi, 2019), especially during the pandemic Covid-19(Rahmania et al., 2020). Even though learning is carried out online, teachers must still develop creativity and innovation in building early childhood character and provide fun learning by utilizing technology (Srihartini \& Lestari, 2020). One of these innovations is implementing learning centers to build early childhood character (Sumiyati et al., 2020).

By implementing a learning center to build early childhood character, teachers, in this case, parents, will have no trouble because learning is child-centered. Parents as teachers only need to be motivators and facilitators. In contrast, learning is wholly left to children to determine for themselves what activities are of interest. Thus children have the opportunity to develop their abilities freely and with direction.

\section{CONCLUSIONS AND SUGGESTIONS}

Building children's character from an early age is a must to give birth to a golden generation. Learning center is the best alternative to building early childhood character because it emphasizes the aspects of play according to early childhood development. Based on an analysis of 95 articles from various countries, it is found that the application of the learning center method can be used as a solution to building the early childhood character in the current situation of the pandemic Covid-19 by maximizing cooperation between teachers and parents. Therefore, the application of

the learning center method needs to be supported through continuous special training for teachers. The researchers suggest using the learning center method to build early childhood character. It should be used or applied as often as possible so that early childhood character development can be maximized and embedded in children until their adulthood.

\section{ACKNOWLEDGMENTS.}

Thanks to Mr. Syafrimen, M.Ed, Ph.D. who has guided the researchers extensively in designing this article to become a scientific article that deserves to be used as a reference, especially in Early Childhood Islamic Education. Also, thanks to Mr. Cahniyo Wijaya Kuswanto, M.Pd., who also provided tremendous assistance in completing this article. 


\section{REFERENCES}

Abdi, M. I. (2018). The Implementation of Character Education in Kalimantan, Indonesia: Multi Site Studies. Dinamika Ilmu, 18(2), 305-321. https://doi.org/10.21093/di.v18i2.1289

Afandi, I., \& Juanda. (2020). Application of Character Education Values in Early Childhood Through Online Fables. AKSIS: Jurnal Pendidikan Bahasa Dan Sastra Indonesia, 4(1), 85-100.

Agusti, F. A., Zafirah, A., Anwar, F., \& Syafril, S. (2018). The Implantation of Character Values toward Students through Congklak Game. Jurnal Penelitian Pendidikan, 35(2), 133-141. https://journal.unnes.ac.id/nju/index.php/JPP/article/view/13947

Anggraini, E. S. (2020). Penanaman Nilai Karakter Anak Usia Dini Pada Model Pembelajaran Bcct ( Beyond Centers And Circle Time ) Di TK Pembina Sukaramai , Kecamatan Kerajaan, Kabupaten Pakpak Baharat. Jurnal Usia Dini, 6(2), 20-27.

Anggraini, W., \& Syafril, S. (2018). Pengembangan Nilai-Nilai Moral dan Agama pada Anak Usia Dini. https://doi.org/10.31219/osf.io/dbnya

Anhusadar, L. O. (2019). Buku Panduan Pembelajaran Di Tk / Ra Berbasis Sentra (Issue August).

Anna Fauza Jailani, Zulfadli A. Aziz, S. S. F. (2018). Improving Speaking Skills Using the Beyond Centers and Circle Time (BCCT) Technique. English Education Journal, 9(3), 443-465.

Apriliani, M., Rusdiyani, I., \& Sayekti, T. (2020). PENERAPAN PENDEKATAN BCCT (BEYOND CENTER AND CIRCLE TIME) BERBASIS KECERDASAN JAMAK. JPP PAUD FKIP Untirta, 7(2), 145-158.

Arifin, A.-R. K., \& Fardana, N. A. (2014). Peran Pendidik PAUD dalam Mengimplementasikan Pendidikan Karakter Melalui Metode Pembelajaran Sentra dan Lingkaran. Jurnal Psikologi Pendidikan Dan Perkembangan, 3(3), 188-198. http://journal.unair.ac.id/filerPDF/jpppaa5c340a9efull.pdf

Arwen, D., \& Puspita, D. R. (2020). The Role of Technology on Students' Character Education. Journal of Physics: Conference Series, 1477(4). https://doi.org/10.1088/17426596/1477/4/042070

Astuti, R. W., Waluyo, H. J., \& Rohmadi, M. (2019). Character Education Values in Animation Movie of Nussa and Rarra. Budapest International Research and Critics

Institute (BIRCI-Journal): Humanities and Social Sciences, 2(4), 215-219. https://doi.org/10.33258/birci.v2i4.610

Atmazaki, Agustina, Indriyani, V., \& Abdurahman. (2020). TEACHERS PERCEPTION OF CHARACTER EDUCATION INTEGRATION IN LANGUAGE LEARNING. Jurnal Pendidikan Karakter, X(2), 634.

Bahar, H., Iswan, Sundi, V. H., \& Fitri, N. L. (2020). PEMBELAJARAN BEYOND CENTERS AND CIRCLE TIME (BCCT) BERBASIS AL-QUR'AN DALAM PENINGKATAN NILAI-NILAI KARAKTER BAGI ANAK USIA DINI. Jurnal Pendidikan Anak Usia Dini, 4(2).

Bustan, R., \& Fitria, N. (2017). Pelatihan Kiat Membangun Karakter Anak. JURNAL AlAZHAR INDONESIA SERI HUMANIORA, 4(1). https://doi.org/10.36722/sh.v4i1.250

Chowdhury, M. (2016). Emphasizing Morals, Values, Ethics, and Character Education in Science Education and Science Teaching. The Malaysian Online Journal of Educational Sciences (MOJES), 4(2), 1-16.

Cinantya, C., Suriansyah, A., \& Asniwati, A. (2018). the Model of Religion-Based Character Education (Multi-Site Integrated Islamic Paud Sabilal Muhtadain and Paud Islam Mawaddah Banjarmasin, Indonesia). European Journal of Education Studies, 5(7), 1-13. https://doi.org/10.5281/zenodo.1494158 
Dewi, Y. K. (2015). HUBUNGAN ANTARA KEMATANGAN EMOSI ANAK USIA DINI DAN METODE BCCT (BEYOND CENTER AND CIRCLES TIME) DITINJAU DARI PEMAHAMAN ORANG TUA SISWA DAN GURU DI PAUD PELANGI DAN MEGA BUANA.

Dj, M. Z., Telaumbanua, S., Rugaiyah, Gadzali, S. S., Husna, F., \& Pramesworo, I. S. (2020). Application of beyond Centers and Circles Time method to improve writing skills and scientific attitude of prospective english learners. Universal Journal of Educational Research, 8(10), 4939-4945. https://doi.org/10.13189/ujer.2020.081066

Farisia, H. (2020). Nurturing Religious and Moral Values at Early Childhood Education. Didaktika Religia : Journal of Islamic Education, 8(1), 1-27.

Fathinnaufal, M., \& Hidayati, D. (2020). The Implementation of Character Education In Elementary School. Journal of Educational Management and Leadership, 1(2), 31-38. https://doi.org/10.33369/jeml.1.2.31-38

Fatmawati, \& Latif, M. A. (2019). Implementasi Model Pembelajaran Sentra di TK Amal Insani Yogyakarta. Jurnal Ilmiah Tumbuh Kembang Anak Usia Dini, 4(2), 25-34. http://ejournal.uin-suka.ac.id/tarbiyah/index.php/goldenage/article/view/2528/1653

Gunawan, M. T. R. (2020). Children's Rights Urgention in Early Childhood Learning During at Home (Pandemic Covid-19). Proceedings of the 1st International Conference on Early Childhood Care Education and Parenting, 503(Iceccep 2019), 99-104. https://doi.org/10.2991/assehr.k.201205.093

Gunawan, R. (2017). The Role of Character Education for Early Children in Early Childhood Education Programs in Happy Kids Bogor Indonesia. Advances in Social Science, Education and Humanities Research (ASSEHR), 66(Yicemap), 23-26. https://doi.org/10.2991/yicemap-17.2017.5

Hadiati, E., \& Fidrayani, F. (2019). Manajemen Pembelajaran Pendidikan Anak Usia Dini. Al-Athfaal: Jurnal Ilmiah Pendidikan Anak Usia Dini, 2(1), 69-78. https://doi.org/10.24042/ajipaud.v2i1.4818

Hapidin, \& Yenina. (2016). Pengembangan Model Permainan Tradisional dalam Membangun Karakter Anak Usia Dini. Jurnal Pendidikan Usia Dini, 10(2), 201-212. https://doi.org/https://doi.org/10.21009/JPUD.102.01

Hasanah, N., \& Harmawati, D. (2020). Manajemen Pembelajaran Taman Kanak-Kanak Model Sentra dengan Pendekatan Beyond Centers And Circle Time ( BCCT ). PEMBELAJAR: Jurnal Ilmu Pendidikan, Keguruan, Dan Pembelajaran, 4(1), 30-33. https://doi.org/10.26858/pembelajar.v4i1.11248

Hasanah, R., \& Abdul, M. (2019). Implementasi Model Pembelajaran BCCT ( Beyond Centers And Circle Times ) dan Model Pembelajaran Konsiderasi di TK Khalifah Baciro Kota Yogyakarta. Al-Mudarris : Jurnal Ilmiah Pendidikan Islam, 2(2), 184-199.

Hendra Sofyan, Muazzomi, N., \& Lestari, N. (2019). The Identification of Implementation of Learning center Models. 382(Icet), 265-268. https://doi.org/10.2991/icet-19.2019.67

Heriansyah, H. (2018). THE IMPORTANCE OF CHARACTER EDUCATION : THE ENGLISH TEACHER' $\mathrm{S}$ EFFORTS AND CHALLENGES IN STUDENT $\mathrm{S}$, CHARACTER BUILDING Hendra Heriansyah Department of English Education, Syiah Kuala University, Indonesia Email: hendrisa@unsyiah.ac.id. Proceedings of the International Conference on the Roles of Parents in Shaping Children's Characters (ICECED), 429-434.

Hignasari, L. V., \& Wijaya, I. K. W. B. (2020). Impact Analysis of Online Learning Toward Character Education of Elementary School Students In The New Normal Era. New Normal : Idealism and Implementation in Indonesia and Philippines, 225-244. 
Indriani, D. E. (2017). CHARACTER EDUCATION BASED ON PANCASILA VALUES THROUGH CURRICULUM 2013 ON PRIMARY EDUCATION CHILDREN IN MADURA. Jurnal Pendidikan Dasar Indonesia, 2(1), 13-17.

Iswantiningtyas, V., \& Wulansari, W. (2019). Penanaman Pendidikan Karakter pada Model Pembelajaran BCCT (Beyond Centers and Circle Time). Jurnal Obsesi: Jurnal Pendidikan Anak Usia Dini, 3(1), 110. https://doi.org/10.31004/obsesi.v3i1.106

Jain, S., Reno, R., Cohen, A. K., Bassey, H., \& Master, M. (2019). Building a culturallyresponsive, family-driven early childhood system of care: Understanding the needs and strengths of ethnically diverse families of children with social-emotional and behavioral concerns. Children and Youth Services Review, 100(February), 31-38. https://doi.org/10.1016/j.childyouth.2019.02.034

Khairunisa, A., \& Wahab, R. (2019). Synergy Between Character Education and Local Wisdom. 326(Iccie 2018), 64-70. https://doi.org/10.2991/iccie-18.2019.12

Kholifah, R. N., Hendarwati, E., \& Setiawan, A. (2018). PENGARUH STRATEGI PEMBELAJARAN BEYOND CENTERS AND CIRCLETIME (BCCT) TERHADAP KREATIFITAS ANAK USIA DINI KELOMPOK USIA 3-4 TAHUN DI POS PAUD NUSA INDAH SURABAYA. PEDAGOGI: Jurnal Anak Usia Dini Dan Pendidikan Anak Usia Din, 4(1), 75-89.

Kim, S., Choe, I., \& Kaufman, J. C. (2019). The development and evaluation of the effect of creative problem-solving program on young children's creativity and character. Thinking Skills and Creativity, 33(August), 100590. https://doi.org/10.1016/j.tsc.2019.100590

Kiritin, A., \& Darsono, K. (2019). the Importance of Character Education in Forming Mental Quality of Enterpreneurs To Open Work Fields. International Journal on Recent Trends in Business and Tourism, 3(2), 13-20.

Kristjánsson, K. (2020). Recent attacks on character education in a UK context: a case of mistaken identities? Journal of Beliefs and Values, 00(00), 1-15. https://doi.org/10.1080/13617672.2020.1848151

Lestari, S. (2016). The Implementation of Beyond Centers and Circle Times (BCCT) in Early Childhood Education. 14, 363-366. https://doi.org/10.2991/icemal-16.2016.76

Lestari, Syafril, S., Latifah, S., Engkizar, E., Damri, D., Asril, Z., \& Erlina, N. (2021). Hybrid learning on problem-solving abiities in physics learning: A literature review. https://doi.org/10.1088/1742-6596/1796/1/012021

Lucas, F. M. M. (2017). The Game as an Early Childhood Learning Resource for Intercultural Education. Procedia - Social and Behavioral Sciences, 237(June 2016), 908-913. https://doi.org/10.1016/j.sbspro.2017.02.127

Ma'rifah A, U., \& Muthmainnah, A. (2015). Metode Pembelajaran Bcct Dalam Mengembangkan Nilai Moral Pendidikan Karakter Anak Usia Dini. PG-PAUD Trunojoyo, 2(2), 117-124.

Maimunah, Aslamiah, \& Suriansyah, A. (2018). The Integration of Sentra-Based Learning and Involvement of Family Program at Early Childhood in Developing Character Building (Multi Case at PAUD Mawaddah and PAUD Alam Berbasis Karakter Sayang Ibu Banjarmasin, Indonesia). European Journal of Education Studies, 5(7), 49-63. https://doi.org/10.5281/zenodo.1494207

Maputra, Y., Syafril, S., Wekke, I. S., Juli, S., Anggreiny, N., Sarry, S. M., \& Engkizar. (2020). Building Family's Social Resilience through Batobo Culture: A community environment proposal. IOP Conference Series: Earth and Environmental Science, 469(1). https://doi.org/10.1088/1755-1315/469/1/012062

Mardi Fitri, \& Na'imah. (2020). Faktor yang Mempengaruhi Perkembangan Anak Usia Dini. Al-Athfaal: Jurnal Ilmiah Pendidikan Anak Usia Dini, 3(1). https://doi.org/10.33222/pelitapaud.v4i2.968 
Maryatun, I. B. (2016). Peran Pendidik Paud Dalam Membangun Karakter Anak. Jurnal Pendidikan Anak, 5(1), 747-752. https://doi.org/10.21831/jpa.v5i1.12370

Masrurah, E. (2020). IMPLEMENTASI MODEL PEMBELAJARAN BEYOND CENTER AND CIRCLE TIME (BCCT) DALAM UPAYA MENINGKATKAN KREATIVITAS ANAK. Jurnal Al-Ibanah, 05(01).

Mufaziah, E., \& Fauziah, P. (2020). Kendala Orang Tua dalam Mendidik Anak Usia Dini pada Saat Pandemi Covid 19. Jurnal Obsesi : Jurnal Pendidikan Anak Usia Dini, 5(2), 1045-1051. https://doi.org/10.31004/obsesi.v5i2.746

Muhsinin, \& Navi, I. (2017). Efektifitas Pembelajaran Sentra di Kecamatan Trowulan Mojokerto. SELING: Jurnal Program Studi PGRA, 3(2), 107-124. https://doi.org/ISSN:2528-083X

Mulyadi, B. (2020). Early childhood character education in japan. E3S Web of Conferences, 202. https://doi.org/10.1051/e3sconf/202020207063

Murestiyanto, A. O. (2019). Implementation of Character Education in the Process of Learning on Attitude and Social Behavior (The Case Study of Budi Mulia Dua International High School). International Conference on Social Studies, Moral, and Character Education, 323(ICoSSCE 2018), 135-139. https://doi.org/10.2991/icossceicsmc-18.2019.26

Mustajab, Baharun, H., \& Iltiqoiyah, L. (2021). Manajemen Pembelajaran melalui Pendekatan BCCT dalam Meningkatkan Multiple intelligences Anak. Jurnal Obsesi : Jurnal Pendidikan Anak Usia Dini, 5(2), 1368-1381. https://doi.org/10.31004/obsesi.v5i2.781

Mutmainnah. (2020). Strategi Pendidik Anak Usia Dini Era Covid-19 Dalam Menumbuhkan Kemampuan Critical Thinking. PAUD Lectura: Jurnal Pendidikan Anak Usia Dini, 4(1), 87-96. https://doi.org/10.31849/paud-lectura.v\%vi\%i.4982

Novia, A. P., \& Mahyuddin, N. (2020). Pembelajaran Sentra dalam Mengembangkan Kecerdasan Interpersonal Anak. Jurnal Pendidikan Tambusai, 4(2), 1247-1255.

Oktaria, R., \& Putra, P. (2020). CHILD EDUCATION IN THE FAMILY AS AN EARLY CHILDHOOD EDUCATION STRATEGY DURING THE COVID-19 PANDEMIC. Jurnal Ilmiah PESONA PAUD, 7(1), 41-51. https://doi.org/p-ISSN 2337-8301; e- ISSN 2656-1271

Purnama, A., \& Abadi, M. I. (2019). Pengembangan Model Pembelajaran Sentra dan Lingkaran Berbasis Pendidikan Inklusi Untuk Taman Kanak-kanak ( TK ). Jurnal Teladan, 4(1).

Puspita, S. K. E., Ardana, I. K., \& Wiyasa, I. K. N. (2015). Penerapan Model Pembelajaran Kooperatif Tipe Bcct Berbantuan Media Audiovisual Untuk Perkembangan Bahasa Pada Anak Kelompok B3 Tk Kumara Jaya. E-Journal PG-PAUD Universitas Pendidikan Ganesha, 3(1).

Puteri, S., Ali, M., \& Halida. (2018). MODEL PEMBELAJARAN BCCT MELALUI SENTRA SENI UNTUK MENGEMBANGKAN KREATIVITAS ANAK USIA 5-6 TAHUN DI TK ISLAMIYAH. Artikel Penelitian, 7(1).

Rahmania, S., Wijayanti, R., \& Hakim, S. L. (2020). Strategi Orang Tua Dalam Pendampingan Belajar Anak Selama Pandemi Covid-19. Jurnal Kajian Keislaman MultiPerspektif, 1(1).

Rahmawati, D. (2019). Penerapan Pembelajaran Sentra Persiapan Di Tk Aba Al Wafa Yogyakarta.

Ramadhanti, M., \& Safitri, E. R. (2020). Implementasi Pembelajaran Bcct Berbasis Multiple Intelligences Dalam Mengembangkan Karakter Siswa. Faktor Jurnal Ilmiah Kependidikan, $7(1)$, $37-42$. https://journal.lppmunindra.ac.id/index.php/Faktor/article/view/6220 
Ramadhanti, M., Sumantri, M. S., \& Edwita. (2019). PEMBENTUKAN KARAKTER DALAM PEMBELAJARAN BCCT (BEYOND CENTER AND CIRCLE TIME). Jurnal Educate, 4(1).

Rina, N., Suminar, J. R., Damayani, N. A., \& Hafiar, H. (2020). Character education based on digital comic media. International Journal of Interactive Mobile Technologies, 14(3), 107-127. https://doi.org/10.3991/ijim.v14i03.12111

Ruqoyah, A. (2016). PENGARUH MODEL PEMBELAJARAN BEYOND CENTERS AND CIRCLE TIMES ( BCCT ) DAN KEMANDIRIAN TERHADAP KREATIVITAS. $\begin{array}{llll}\text { Jurnal Pendidikan Usia } & \text { 10(1), }\end{array}$ https://doi.org/https://doi.org/10.21009/JPUD.101.05 PENGARUH

Sahudra, T. M., Nurmasytah, N., \& Nursamsu, N. (2020). Application of E-Learning Learning Media with Schoology on Character Education. Budapest International Research and Critics Institute-Journal, 3(3), 2255-2261.

Samsinar, S., \& Fitriani, F. (2020). Character-Based Learning and Self-Development To Improve the Students' Character Education. Lentera Pendidikan : Jurnal Ilmu Tarbiyah Dan Keguruan, 23(1), 108. https://doi.org/10.24252/lp.2020v23n1i10

SANDERIANI, R. (2020). EFEKTIVITAS PENERAPAN MODEL PEMBELAJARAN BEYOND CENTER AND CIRCLE TIME DI TK ISLAM TERPADU MUTIARA HATI SIMPANG III SIPIN KECAMATAN KOTA BARU KOTA JAMBI. Skripsi.

Sari, D. Y., Rahaju, I., \& Noviantoro, N. (2019). Beyond Center Circle Time (BCCT) Parenting-Based Management Dianti. INTERNATIONAL SEMINAR, 63-86.

Satria, Y., \& Kasiyan. (2020). Wayang Suket Representation as a Character Education Media for Children. 3rd International Conference on Arts and Arts Education, 444(Icaae 2019), 138-143. https://doi.org/10.2991/assehr.k.200703.028

Setiawan, J. A., Suparno, Sahabuddin, C., Tasrif, \& Ramadhan, S. (2020). The role of parents on the character education of kindergarten children aged 5-6 years in bima. Universal Journal of Educational Research, 8(3), 779-784. https://doi.org/10.13189/ujer.2020.080307

Setiyarini, E., \& Widiasari, Y. (2017). Hubungan antara Penerapan Pembelajaran BCCT dengan Motivasi Belajar Anak pada Peserta Didik di TB Qita Desa Pamijen Sokaraja Kabupaten Banyumas Semester Genap Tahun Ajaran 2015-2016. SAINTEKS, 14(1), 6569.

Setiyarini, E., Widiasari, Y., Sokaraja, D. P., \& Banyumas, K. (2015). BELAJAR ANAK TAMAN BERMAIN LESSON BCCT AND RELATIONSHIP WITH LEARNING MOTIVATION Oleh : PSYCHO IDEA, 13(2), 34-38.

Shofa, M. F. (2020). Inovasi Pembelajaran pada Pendidikan Anak Usia Dini di Masa Pandemi Covid-19. Buana Gender, 5(2).

Silahuddin. (2017). Urgensi Membangun Karakter Anak Sejak Usia Dini. 3(2), 18-41.

Singh, B. (2019). Character education in the 21st century. Journal of Social Studies (JSS), 15(1), 1-12. https://doi.org/10.21831/jss.v15i1.25226

Sobarna, A., \& Hakim, A. (2017). Management Character Education in Kindergarten. Indonesian Journal of Early Childhood Education Studies, 6(2), 65-73. https://doi.org/10.15294/ijeces.v6i2.20188

Srihartini, Y., \& Lestari, M. P. (2020). Pembelajaran Pendidikan Anak Usia Dini Online di Era Pandemi Covid-19. Journal of Islamic Education, 1(2), 1-20.

Sumiyati, S., Masruri, S., \& Maemonah, M. (2020). Implementasi Model Pembelajaran Sentra pada lembaga Taman Kanak-Kanak di Kabupaten Pati. Jurnal Obsesi : Jurnal Pendidikan Anak Usia Dini, 5(2), 1261-1268. https://doi.org/10.31004/obsesi.v5i2.814 
Supriatna, R., Hafidhuddin, D., \& Syafri, U. A. (2018). Model Pembelajaran Beyond Center and Circle Time (BCCT) BERBASIS Q.S LUKMAN AYAT 12-19. JURNAL PENDIDIKAN ISLAM, 11(2), 1-11.

Suyadi. (2017). Pengembangan Kecerdasan Linguistik (Berbahasa Inggris) melalui Pendekatan BCCT dalam Pembelajaran Anak Usia Dini. Golden Age Jurnal Ilmiah Tumbuh Kembang Anak Usia Dini, 2(2), 2.

Syafril, S, Asril, Z., Engkizar, E., Zafirah, A., Agusti, F. A., \& Sugiharta, I. (2021). Designing prototype model of virtual geometry in mathematics learning using augmented reality. Journal of Physics: Conference Series. https://doi.org/10.1088/1742-6596/1796/1/012035

Syafril, Syafrimen, Rahayu, T., Al-Munawwarah, S. F., Satar, I., Halim, L. B., Yaumas, N. E., \& Pahrudin, A. (2021). Mini Review : Improving Teachers' Quality in STEM-based Teaching- Learning in Secondary School. Journal of Physics: Conference Series. https://doi.org/10.1088/1742-6596/1796/1/012072

Syafril, Syafrimen, Siregar, M., Atmojo, W. T., Pahrudin, A., \& Sanjaya, D. (2020). EIGHT ASPECTS OF MOTIVATIONAL DEVELOPMENT AMONG TEACHERS. Palarch's Journal Of Archaeology Of Egypt/Egyptology, 17(4), 15-26.

Tatminingsih, S. (2019). Alternatif Stimulasi Kemampuan Kognitif melalui Penerapan Model Pembelajaran Berbasis Permainan Komprehensif. Jurnal Obsesi: Jurnal Pendidikan Anak Usia Dini, 3(1), 183. https://doi.org/10.31004/obsesi.v3i1.130

Ulfah, Y. F. (2020). OPTIMALISASI FUNGSI MEDIA SOSIAL SEBAGAI SARANA PUBLIKASI HOME LEARNING. JOEAI (Journal of Education and Instruction), 3(2), 361-370. https://doi.org/https://doi.org/10.31539/joeai.v3i2.1829

Van Acker, V., Mulley, C., \& Ho, L. (2019). Impact of childhood experiences on public transport travel behaviour. Transportation Research Part A: Policy and Practice, 130(July 2018), 783-798. https://doi.org/10.1016/j.tra.2019.10.008

Wahyuningsih, D. (2020). MODEL PEMBELAJARAN BCCT BAGI ANAK USIA DINI SESUAI DENGAN TAHAP PERKEMBANGAN. Jurnal Pendidikan Anak Usia Dini, $3(1)$.

Widiastuti, A., Pusari, R. W., \& Diyah H, D. P. (2019). Analisis Metode Pembelajaran Beyond Center and Circle Time (Bcct) Terhadap Perkembangan Sosial Anak Usia 3-4 Tahun Di Tk Mnu Masyithoh 95. PAUDIA : Jurnal Penelitian Dalam Bidang Pendidikan Anak Usia Dini, 8(1), 110-117. https://doi.org/10.26877/paudia.v8i1.3886

Widyastuti, L., Khasanah, I., \& Rakhmawati, E. (2018). Penerapan Pembelajaran Model Sentra Alam Pada Kelompok B. 2(3), 238-246.

Wiwik Pratiwi. (2017). Konsep Bermain Pada Anak Usia Dini. Manajemen Pendidikan Islam, 5(2), 106-117.

Wulandari, M. D., \& Filmayasari, D. (2018). Character Education of Care About Environment. The 3rd Progressive and Fun Education International Seminar, August, 7 9.

Wulandari, R. T. (2017). The Implementation of Song and Motion Learning Through the Model of Beyond Center Circles Time(Bcct) to Improve Early Childhood Creativity. 118(c), 7-12. https://doi.org/10.2991/icset-17.2017.2

Xiang, Y., Cao, Y., \& Dong, X. (2020). Childhood maltreatment and moral sensitivity: An interpretation based on schema theory. Personality and Individual Differences, 160(February), 109924. https://doi.org/10.1016/j.paid.2020.109924

Yadnyawati, I. A. G. (2019). MODEL PEMBELAJARAN BEYOND CENTER AND CIRCLE TIME (BCCT) PADA ANAK USIA DINI. Prosiding Seminar Nasional Dharma Acarya Ke-1, 43-50. 
Yuningsih, S., Rifai, A., \& Kisworo, B. (2018). PENYELENGGARAAN PEMBELAJARAN MODEL BEYOND CENTERS AND CIRCLE TIME (BCCT) PADA ANAK USIA DINI. 3(2), 176-183.

Yusnita, E. (2019). STRATEGIC MANAGEMENT MODEL DEVELOPMENT BASED ON BCCT ( Beyond Center and Circle Time ) in PAUD. INTERNATIONAL SEMINAR, 87-94.

Yusuf, F., \& Akbar, M. (2020). The Development of Sentra Learning Model to Build Early Childhood Characters in Kindergarten School. 3rd International Conference on Education, Science, and Technology, 481(Icest 2019), 308-313. https://doi.org/10.2991/assehr.k.201027.064

Zurqoni, Retnawati, H., Apino, E., \& Anazifa, R. D. (2018). Impact of character education implementation: A goal-free evaluation. Problems of Education in the 21 st Century, 76(6), 881-899. https://doi.org/10.33225/pec/18.76.881 